\title{
Oxidative alterations during human platelet storage
}

\author{
Bahar Göker ${ }^{1}$, Derya Özsavcı'1, Azize Şener ${ }^{1}$, Halil Aksoy1', Vedat Bağışgil1, \\ Gülderen Yanıkkaya-Demirel2 ${ }^{2}$, Fikriye Uras ${ }^{1}$
}

\begin{abstract}
SUMMARY: During storage of platelet obtained by apheresis several changes occur. The aim of this study was to investigate the effect of storage on activation, apoptosis, protein pattern, lipid peroxidation, and the levels of nitric oxide (NO) and glutathione (GSH) of platelets. In this study, platelets obtained from healty donors $(n=7)$ by apheresis were kept in an agitator for nine days at $20-24^{\circ} \mathrm{C}$. The samples were taken on the $1 \mathrm{st}, 3 \mathrm{rd}, 5$ th and 9 th days and platelets were precipitated. Platelet activation with PAC-1 and CD62-P antibodies and platelet apoptosis were measured with Annexin-V using flow cytometer. Platelets were frozen and thawed four times and then NO, GSH and malondialdehyte (MDA) levels were assayed by spectrophotometry. Platelets protein pattern was investigated via sodium dodecyl sulfate polyacrylamide gel electrophoresis (SDS-PAGE) procedure. When compared to the 1st day, platelet CD62-P, PAC1 expressions and Annexin-V levels significantly increased on the 3rd, 5 th and 9th days, while platelet NO and GSH levels significantly decreased on the 3rd, 5th and 9th days. Furthermore MDA levels significantly increased on only the 5th and 9th days. Mild changes occurred in the density of platelet protein bands. In conclusion, our results show that alterations of platelet activity during storage period may enhance platelet procoagulant activity which increases trombogenic risk. Therefore, for transfusion using fresh platelets or adjusting platelet preservation are strongly important for platelet behavior in vivo conditions.
\end{abstract}

KEY WORDS:Transfusion, platelet, activation, apoptosis, protein
AFFILIATIONS

1 Marmara

Üniversitesi,Eczacılık

Fakültesi, Biyokimya AD,

İstanbul, Türkiye

2 Yeditepe Universitesi, Tıp

Fakültesi, Tıbbi Mikrobiyoloji

$A D$, İstanbul, Türkiye

CORRESPONDENCE

Derya Özsavcı

E-mail: deryaozsavci@

hotmail.com

\section{Received:}

17.12.2010

Revision

27.12.2010

Accepted:

31.12.2010

\section{INTRODUCTION}

Platelets play an important role in maintaining hemostasis. Platelet transfusions are essential for the treatment of patients with thrombocytopenia and thus routinely used during surgery, chemotherapy and for bleeding disorders. Different separation methods are described to prepare therapeutic platelet concentrates from human donor blood $(1,2)$. In platelets obtained with these methods including apheresis, several changes may occur in morphology, adhesion and aggregation, membrane features (protein pattern), activation and apoptosis markers during prolonged storage (1). There are several receptors on platelet membrane which mediate adhesion, aggregation (Glycoprotein (Gp) IIb/IIIa/ fibrinogen receptor), activation (P-selectin) and other cellular events. Activation signals lead to variations in platelet membrane $\mathrm{Gp}$ receptor expressions and this situation may affect platelet functions (3).In recent years, by using fluorescently labelled antibodies receptor changes are easily detected on platelets. It has been shown that platelet membrane Gp expressions and platelet GSH levels change during the preparation of platelet concentrates and storage $(4,5)$.

On the other hand, nitric oxide synthase (NOS) has been identified in platelets and it is important in the regulation of platelet recruitment (6). Moreover, the decrease in platelet NO increases platelet activation and cellular production of $\mathrm{O}_{2}$ radicals thus lipid peroxidation. Lipid peroxidation of membranes induced by reactive oxygen species alters the structure and function of membrane components followed by the platelet signaling pathway activation. Additionally, although platelets are anucleated cells, apoptosis like events take place both in vivo and in vitro and they can also synthesize proteins by using several transport mechanisms and the amino acids contents in their cytoplasms $(7,8,9)$. PS (phosphatidylserine) exposure is recognized as a marker of cell death as well as being an activation marker. 


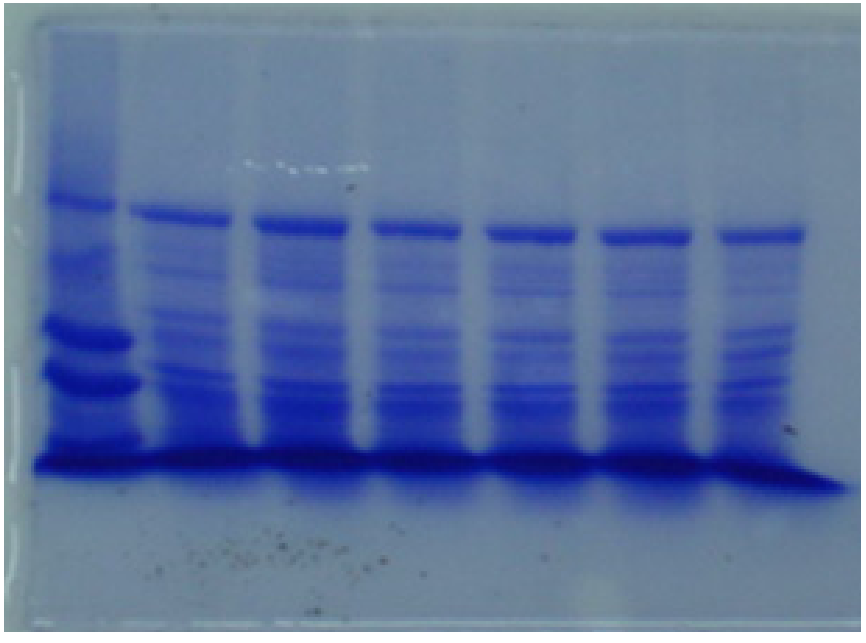

FIGURE 1. Sodium dodecyl sulfate polyacrylamide gel electrophoresis (SDSPAGE) in platelet samples obtained from aphaeresis between the 1st and 9th days

Chronically elevated or prolonged exposure of PS on the cell surface increases vascular damage and results in the formation of a hypercoagulable environment in platelets $(10,11,12)$.

The aim of this study was to investigate the effect of storage on activation, apoptosis, protein pattern, lipid peroxidation, NO and GSH levels of platelets obtained from aphaeresis; and in case there were significant alterations, the aim was to interpret how they would influence platelet functions in vivo.

\section{MATERIAL AND METHODS Materials}

SDS-6H Protein Standard, bisacrylamide, bovine serum albumin (BSA), bromophenol blue coomassie brilliant blue R 250, ethylene diamine tetra-acetic acid (EDTA), HEPES, glycerin, Phosphate-buffered saline (PBS), sodium citrate, reduced glutathione (GSH), Triton X-100, 5-5-dithiobis-2-nitrobenzoic acid (DTNB), adenosine diphosphate (ADP), paraformaldehyde (PFA) were from Sigma (St.Lous,MO,USA); methanol, ammonium persulfate, sodium carbonate, TRIS, sodium potassium tartrate, copper sulphate, thiobarbituric acid (TBA), were from Merck (Darmstadt,Germany); Annexin-V-FITC (Annexin-V-fluorescein isothiocyanate) Apoptosis Detection Kit, binding buffer and FITC anti-human CD62-P were from Becton Dickinson Pharmingen (San Diego, CA,USA); PAC-1 FITC was from Becton Dickinson Biosciences (San Jose, USA).

\section{Subject Criteria}

The participants of this study are healthy voluntary blood donors who regularly donate blood at the Blood Center of İstanbul University Cerrahpasa Medical School and have given consent. The subjects' ages were between 20 and 40 . The routine anamnesis and physical examination of the subjects were performed. Serological scanning tests were applied. Subjects didn't take any medication 10 days prior to the aphaeresis.

\section{Obtaining Platelet Suspension with Apheresis and Preparation of Platelet Samples}

In this study, the platelets obtained from healthy donors $(n=7)$ by the aphaeresis method were kept in an agitator under in-

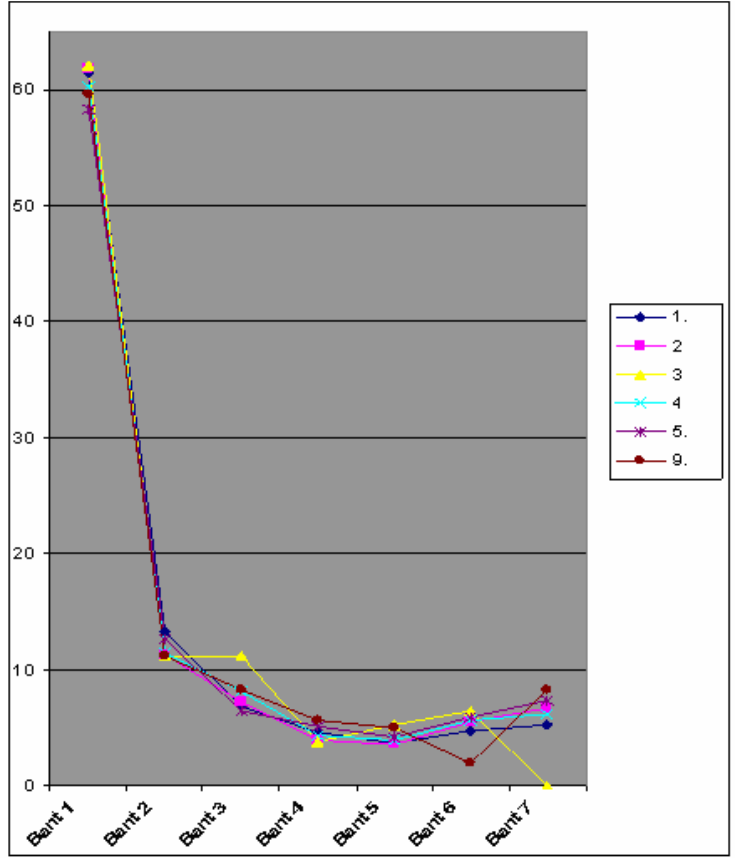

FIGURE 2. Density of platelet protein bands determined from SDS-PAGE in platelet samples from aphaeresis

vitro conditions for nine days at $20-24^{\circ} \mathrm{C}$. The samples were taken on the $1^{\text {st }}, 3^{\text {th }}, 5^{\text {th }}$ and $9^{\text {th }}$ days. After the centrifugation (9000 rpm, $4^{\circ} \mathrm{C}, 15 \mathrm{~min}$, Hettich, Universal 32R, DLB Labcare, Newport Pagnell, England) process, platelets were isolated and the platelet pellet was washed with Tris- $\mathrm{NaCl}$ buffer $(0.03$ $\mathrm{M}$ Tris, $0.12 \mathrm{M} \mathrm{NaCl}, \mathrm{pH}$ 7.4) containing 5 mM EDTA. The platelets were frozen and thawed 4 times. After centrifugation, the supernatant was obtained. Then the protein concentration was determined with the Lowry method (13) and SDS-PAGE was applied to examine the protein alterations.

\section{Measurement of GSH}

GSH levels were assayed according to the method of Mergel et al. (14) using DTNB. GSH contents of platelets were determined with GSH $(2-30 \mu \mathrm{g} / \mathrm{ml})$ as the standard. The results were expressed as $\mu$ g per $10^{9}$ platelets.

\section{Measurement of Lipid Peroxidation}

For the measurement of lipid peroxidation, the precipitate was solubilized for $5 \mathrm{~h}$ with Tris- $\mathrm{NaCl}$ buffer containing $1 \%$ Triton $\mathrm{X}-100$ at $4^{\circ} \mathrm{C}$ and then centrifuged. Lipid peroxidation was evaluated with TBA according to the method of Buege and Aust by spectrophotometry (15). The results were expressed as $\mathrm{nmol} / 10 \mathrm{mg}$ protein.

\section{Nitrite Assay}

The washed platelets were incubated with $1.44 \mathrm{mmol} / \mathrm{L}$ NADPH for $1 \mathrm{~h}$ at $37^{\circ} \mathrm{C}$. Then, each sample was incubated for $1 \mathrm{~h}$ at $37^{\circ} \mathrm{C}$ after the addition of $20 \mathrm{mU}$ nitrate reductase, which reduced nitrate to nitrite. The platelets were frozen and thawed four times. After centrifugation, the supernatant was allowed to react with Griess reagent to form a chromophore; its absorption was measured subsequently at $546 \mathrm{~nm}$. Sodium nitrite $(0.2$ to $4 \mu \mathrm{M}$ ) was used as the standard (16). 


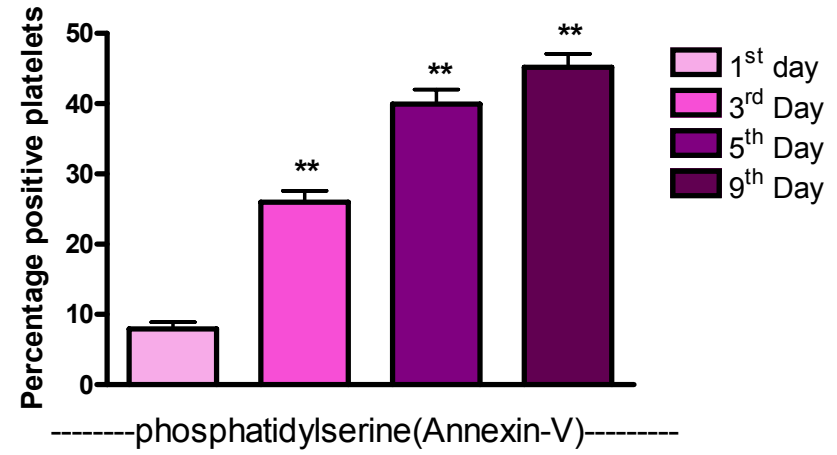

FIGURE 3. Annexin- $V$ expressions in platelet samples from apheresis, ${ }^{*} p<0.01$

\section{Flow cytometric Analysis of Platelet Activation and Apoptosis}

Briefly, washed platelets were diluted in phosphate-buffered saline (PBS) (8 mM NaH2PO4, $5 \mathrm{mM} \mathrm{KCl}, 125 \mathrm{mM} \mathrm{NaCl}, 5 \mathrm{mM}$ glucose and $0.5 \mathrm{~g} / \mathrm{L}$ albumin) and mixed gently. Platelets were identified by staining with FITC conjugated CD41a and by gating from logarithmic scaled forward scatter/side scatter scattergram. FITC-labeled CD62-P (P-Selectin) and PAC-1 (activated $\mathrm{GpIIb} / \mathrm{IIIa}$ ) antibodies were added to each platelet suspension. The tubes were incubated at room temperature, in the dark for 15 minutes for platelet activation analysis. For fixation, PFA (\%1 vol/vol) was added and then the samples were diluted with PBS. All samples were stored at $4^{\circ} \mathrm{C}$ until analysis and analyzed in an hour.

For the measurement of PS exposure, annexin-V-FITC was used. Annexin-V-FITC $(25 \mu \mathrm{g} / \mathrm{ml})$ was added to the diluted samples. Sample tubes were kept on ice until analysis for 10 min in the dark after the addition of an equal volume of cold binding buffer (10mM HEPES/NaOH (pH7.4) $140 \mathrm{mM} \mathrm{NaCl}$, $2.5 \mathrm{mM} \mathrm{CaCl} 2)(17)$.

The analysis of all the samples was carried out in the FACS Calibur flow cytometry system (Becton-Dickinson, Franklin Lakes,

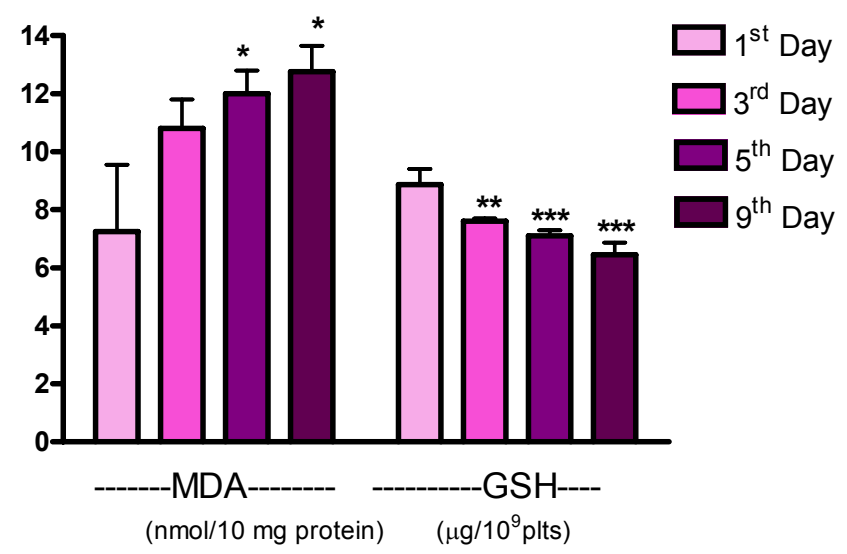

FIGURE 5. MDA and GSH levels in platelet samples from aphaeresis, * $p<0.05$; ** $p<0.01 ;{ }^{* *} p<0.001$

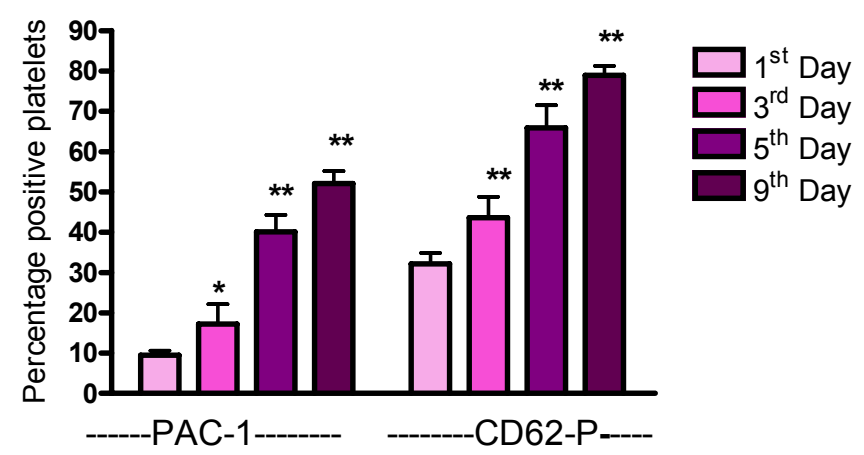

FIGURE 4. PAC-1 (activated Gpllb/llla) and CD62-P (P-selectin) expressions in platelet samples from aphaeresis, ${ }^{*} p<0.05 ;{ }^{* \star} p<0.01$

NJ). The system was equipped with $488 \mathrm{~nm}$ argon ion laser. CaliBrite beads (BD Biosciences, San Jose, CA) were used for daily quality control. 50,000 cells were counted in each tube. The results were expressed as the percentage of positive cells. The negative control cursor was set to $2 \%$ of cells on histograms.

\section{Statistical Analysis}

The results were presented as mean \pm SD. For the daily platelet alterations, analyses were compared using the Wilcoxon signed-rank test. Statistical analyses were performed with Graph Pad Prism 4 software. P values $<0.05$ were considered significant.

\section{RESULTS AND DISCUSSION}

Platelet transfusions are routinely used during surgery and during several conditions resulting in thrombocytopenia such as chemotherapy $(1,5)$. It has been pointed out in several studies that platelets that are kept under the blood bank conditions begin to lose their functions $(18,19)$. Platelets undergo several modifications during storage that reduce their post transfusion functionality. This loss can be observed in the plasma concentrations even in the first 24 hours. There has been debates whether this loss of functions is caused by the platelet activation during the preparation and storage process or by the changes in the $\mathrm{pH}$ and enzyme activation of the plasma envi-

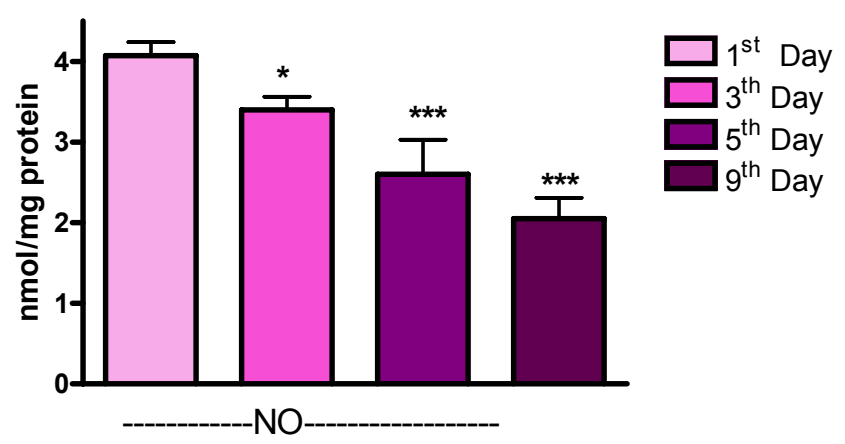

FIGURE 6. NO levels in platelet samples from aphaeresis * $p<0.05 ;{ }^{* \star *} p<0.001$ 


\section{Trombosit depolanması sırasındaki oksidatif değişiklikler}

ÖZET: Transfüzyon için aferezle elde edilen trombositlerde trombosit cevabında depolama sırasında çeşitli değişiklikler oluşur. Bu çalışmanın amacı depolamanın trombosit aktivasyonu, apoptozu, protein içeriği, lipid peroksidasyonu, nitrik oksit (NO) ve glutatyon (GSH) seviyelerine etkisini incelemektir. Bu çalışmada sağlıklı vericilerden aferezle elde edilen trombositler çalkalayıcıda $20-24^{\circ} \mathrm{C}$ 'de 9 gün saklandı.1.,3.,5.,9. günlerde trombositler toplandı ve çöktürüldü. Trombosit aktivasyonu PAC-1 ve CD62-P antikorları ile, trombosit apoptozu ise Annexin-V ile flovsitometrede ölçüldü.Trombositler dört kez eritip donduruldu ve sonra NO, GSH ve malondialdehit (MDA) seviyeleri spektrofotometre ile tayin edildi. Protein dağılımı sodyum dodesil sülfat poliakrilamid jel elektroforezi (SDS-PAGE) ile araştırıldı. 1. günle karşılaştırıldığında, CD62-P, PAC-1 ekspresyonları ve Annexin-V seviyeleri 3.,5., ve 9., günlerde anlamlı düzeyde arttı. 1. günle karşılaştırıldığında trombosit NO ve GSH seviyeleri 3., 5., ve 9. günlerde azaldı, bununla birlikte MDA seviyeleri sadece 5. ve 9. günlerde anlamlı düzeyde arttı. Trombosit protein bandlarında hafif değişiklikler gözlendi. Bizim sonuçlarımız transfüzyon için hazırlanan trombositlerde trombosit aktivitesindeki değişikliklerin ilerde in vivo dolaşımda prokoagulant aktiviteyi ve böylece trombojenik riski artırabileceğini göstermektedir. Bu nedenle transfüzyon için taze örneklerin kullanılması ya da trombositlerin iyi korunması in vivo durumdaki trombosit davranışı için çok önemlidir.

ANAHTAR KELIMELER: Transfüzyon, trombosit, aktivasyon, apoptoz, protein

ronment. Perhaps both mechanisms are responsible for this phenomenon.

In this study, we first detected percentage of protein levels of SDS-PAGE bands determined from densitometry in platelets (figure 1). In several studies carried out so far, approximately 2,300 proteins have been detected in platelets. Some abnormalities can be seen in platelet functions resulting from several protein deficiencies and defects. Since signalling proteins trigger major processes in platelets, especially loss of signalling proteins is very important for their survival. George NJ et al. (20) demonstrated major glycoprotein loss (later this protein is termed GPIb) after electrophoresis in storage platelets. In the present study, the alterations on the membrane protein bands between the first and ninth days were investigated and mild changes were observed in the density of platelet protein bands (figure 2). However, we should point out that we examined only the platelet membrane proteins in this study; we didn't determine the changes in the cytological proteins. Further studies are needed in order to show all the changes in all the protein content.

It is known that activation is the most abundant process in platelets and essential for platelet aggregation and coagulation. On the other hand, platelets undergo apoptosis in various conditions and contain at least some of the machinery necessary for apoptosis, such as caspases and death receptors. PS becomes exposed on the outer cell membranes during the early stages of apoptosis. At the same time, PS exposure is reported to be a predictor of platelet activation as well as being an apoptotic marker (21). For measurement of platelet activation and apoptosis, several monoclonal antibodies have been described that recognize antigens on platelets. PAC-1 has been used identifying fibrinogen receptor GpIIb/IIIa in activated platelets (22). Additionally, P-selectin is only expressed on the platelet surface after a-granule secretion thus after activation (23). Recent studies proved that the increased expression of the P-selectin correlates with the in vivo recovery of transfused platelets (24). PS exposure on the surface of cells is commonly measured by flow cytometry of fluorescently labeled Annexin-
$\mathrm{V}$ binding to this procoagulant phospholipid (25). In several studies, it was shown that platelet membrane markers including CD62-P, CD63 and Annexin-V increased during prolonged storage (26). Platelets exhibit changed membrane features, increased expression of pro-apoptotic markers and they lose viability during in vitro storage. In fact, the life span of platelets in the human circulation is estimated to be 10 to 12 days. However, after 5 to 6 days of in vitro storage, platelets lose their viability and activity. Therefore, we detected by flow cytometry binding of Annexin- $\mathrm{V}$ for platelet apoptosis (at the same time a platelet activation marker) (figure 3 ) and the expression of PAC-1 and CD62-P for platelet activation (figure 4) in platelets prepared by aphaeresis. In this study, when compared to the 1st day, platelet CD62-P, PAC-1 expressions (the percentage of CD-62 and PAC-1 positive cells) and Annexin-V levels significantly increased $(\mathrm{p}<0.01)$ on the $3 \mathrm{rd}, 5$ th and 9 th days. Our results are consistent with other studies. The activation criteria that we found show that as the storage time of platelets is prolonged, activation potentiality will increase, there will be more sensitivity to agonists following transfusion, and thus they will be inclined to aggregation. Additionally, in prolonged storage increased PS exposure increases procoagulant activity and may cause a prothrombotic condition thus thromboembolic risk.

In this study, we also determined oxidative stress parameters and platelet NO levels during platelet storage. There is strong evidence that oxidative stress is a mediator of apoptosis. Additionally, in this study, when compared to the 1st day, platelet NO and GSH levels significantly decreased on the 3rd, 5th and 9th days; whereas, MDA levels significantly increased on only the 5 th and 9 th days $(\mathrm{p}<0.05)$. It was shown that the decrease in platelet NO increases platelet activation and lipid peroxidation (27). Low nitrite levels observed in the study may indicate that some factors are responsible for the increase in platelet activation, platelet lipid peroxidation and apoptosis. It is still a complicated phenomenon whether resulting oxidative changes trigger activation and apoptosis or activation and apoptosis trigger oxidative changes depending on storage. 
In conclusion, our results show that the increase of apoptosis, activation and lipid peroxidation and decrease of $\mathrm{NO}$ and GSH in platelets prepared for transfusion will enhance platelet procoagulant activity thus trombogenic risk in in vivo circulation. On the other hand, storage leads to defects in platelet activation properties, thus their clearance by macrophages. The use of updated storage methods will help to generate platelets for transfusion with optimal haemostatic function and a long circulation time after transfusion. At the same time using fresh platelets and adjusting platelet preservation are strongly important for platelet functions in in vivo conditions.

\section{ACKNOWLEDGEMENTS}

We are grateful to Prof.Dr.Birsen Yalçın Ülkü and Mr. Nazmi Uzunosmanoglu for their contribution to the preparation of this manuscript.

\section{REFERENCES}

1. Thon JN, Schubert $P$, Devine DV. Platelet storage lesion: a new understanding from a proteomic perspective. Transfus Med Rev, 22:268-79, 2008.

2. Eva M. Martın V, Jesus $S Y$, Marina $C R$, Francisco PG, Marcial L. Comparasion between in vitro lipid peroxidation in fresh sheep platelets and peroxidative processes during sheep platelet ageing under storage at $4^{\circ} \mathrm{C}$. Biochimica et Biophysica Acta, 1419: 313-324,1999.

3. Ozsavci D, Yardimci T, Demirel GY, Demiralp E, Uras F, Onder E. Flow cytometric assay of platelet glycoprotein receptor numbers in hypercholesterolemia. Platelets, 13:223-229, 2002.

4. PT Burch, JW Burch. Alterations in glutathione during storage of human platelet concentrates. Transfusion, 27:342-46, 1986.

5. Matsubayatsi E, Weidner J, Miraglia CC, Mcintyre JA. Platelet membrane early activation markers during prolonged storage. Thromb Res, 93:151-60, 1999.

6. Jane E. F, Joseph L, Marc RB, Caroline a, John FK, Alan DM. Nitric oxide rleased from activated platelets inhibits platelet recruitment. J Clin Investigation, 2:350-56, 1997.

7. Sener A, Ozsavc1 D, Oba R, Demirel YG, Uras F, Yardimc1 KT.. Do platelet apoptosis, activation, aggregation, lipid peroxidation and platelet-leukocyte aggregate formation occur simultaneously in hyperlipidemia? Clinical Biochemistry, 38: 1081-1087, 2005.

8. Warshaw A.L., Laster L., Shulman N.R.: Protein synthesis by human platelets. J Biol Chem, 242:2094-7,1967.

9. Yardimcı T.U.: Membrane transport systems in human platelets. Hematologica, 65: 498-508,1980.

10. Brown, S.B., Clarke, M.C., Magowan, L., Sanderson, H. \& Savill, J. Constitutive death of platelets leading to scavenger receptor-mediated phagocytosis. A caspase independent cell clearance program. Journal of Biological Chemistry, 275: 5987-5996, 2000.

11. Tonon $G$, Lua X, Greco NJ, Chen $W$, Shi $Y$, Jamiesan GA.. Weak platlet agonist and U46619 induce apoptosis-like events in platelets, in the absence of phosphatidlyserine exposure. Thromb Res, 15: 425-50, 2002.
12. Rand ML, Wang $H$, Bang KWA, Poon KSV, Packham MA, Freedman J. Procoagulant surface exposure and apoptosis in rabbit platelets: association with shortened survival and steady state. J Thromb Haemost, 2: 651-59, 2003.

13. Lowry O.H., Rosebrough N.J., Farr A.L, Randall R.H. Protein measurement with the folin phenol reagent. J Biol Chem, 193:265.1951.

14. Mergel, D. C., Anderman, G. Simultaneous determination of oxidized and reduced glutathione in human rabbit red cells. Methods Find. Exp. Clin. Pharmacol, 1:277283, 1979.

15. Buege, J. A., Aust, S. D. Microsomal lipid peroxidation. Methods Enzymol, 52:302-310, 1978.

16. Chen LY, Mehta P, Mehta JL. Oxidized LDL decreases Larginine uptake and nitric oxide synthase protein expression on human platelets. Circulation, 93:1740-6, 1996.

17. Azize Sener, Derya Ozsavci, Ozlem Bingol-Ozakpinar, Ozge Cevik, Gulderen Yanikkaya-Demirel, Turay Yardimci. Oxidized-LDL and Fe3+/ascorbic acid-induced oxidative modifications and phosphatidylserine exposure in human platelets are reduced by melatonin. Folia-Biologica, 55:45-52, 2009.

18. van der Wal DE, Du VX, Lo KS, Rasmussen JT, Verhoef S, Akkerman JW. Platelet apoptosis by cold-induced glycoprotein Iba clustering. J Thromb Haemost, 23:25542562, 2010.

19. Jackson SP, Schoenwaelder SM. Procoagulant platelets: are they necrotic? Blood, 116:2011-8, 2010.

20. George J.N.: Platelet membrane glycoproteins: alteration during storage of human platelet concantrates. Thromb Res, 8:719-724,1976.

21. Lentz BR. Exposure of platelet membrane phosphatidylserine regulates blood coagulation. Prog Lipid Res, 42:423-38, 2003.

22. Shattil SJ, Cunningham $M$, Hoxie JA. Detection of activated platelets in whole blood using activation-dependent monoclonal antibodies and flow cytometry. Blood, 70:307-15, 1987

23. van der Zee PM, Biró $E$, Ko $Y$, de Winter RJ, Hack $C E$, Sturk A, Nieuwland R. P-selectin- and CD63-exposing platelet microparticles reflect platelet activation in peripheral arterial disease and myocardial infarction. Clin Chem, 52:657-64, 2006.

24. Dittmann J, Riggert J, Wieding JU, Simson G, Köhler M. Platelet membrane glycoproteins in thrombocytapheresis and platelet concentrates. Beitr Infusionsther Transfusionsmed, 32:422-7, 1994

25. Perrotta PL, Perrotta CL, Snyder EL. Apoptotic activity in stored human platelets. Transfusion, 43:526-35, 2003.

26. Metcalfe P, Williamson L.M, Reutelingsperger C.P.M, Swann I, Ouwehand W.H, Goodall A.H. Activation during preparation of therapeutic platelets affects determination during storage: a comparative flow cytometric study of different production methods. British Journal of Haematology, 98:86-95,1997.

27. Williams RH, Nollert MU. Platelet-derived NO slows thrombus growth on a collagen type III surface. Thromb J, 2:11-20, 2004. 